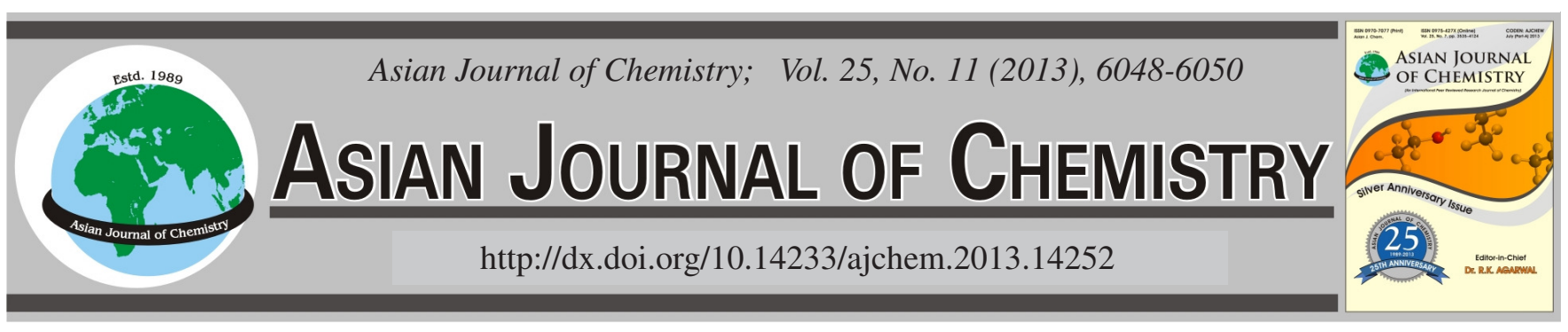

\title{
GC-MS Analysis of the Steam and Hydrodistilled Essential Oil of Matricaria recutita L. Flowers of North East Region of India
}

\author{
Sudeer Tandon, Jamil Ahmad and Ateeque Ahmad*
}

Process Chemistry and Technology Department, Central Institute of Medicinal and Aromatic Plants, Lucknow-226 015, India

*Corresponding author: E-mail: ateeque97@gmail.com

(Received: 30 June 2012;

Accepted: 26 April 2013)

AJC-13398

\begin{abstract}
The composition of the flowers of Matricaria recutita ( Chamomile) steam (I) and hydro distilled (II) essential oil of north east regions of India were examined by gas chromatographic-mass spectroscopic analysis. The essential oil yield (mL/100 g dry weight) were $0.40 \%$ and $0.50 \%$, respectively. Thirty two and 34 compounds comprising 99.95 and $100 \%$ of the total peak area were identified in the (I) and (II) respectively. The common major components of essential oils have been identified as $\beta$-farnesene $(10.23,11.96 \%)$, trans-limonene oxide (3.48, $3.31 \%)$, bisabolol oxide B $(16.91,17.43 \%), \alpha$-bisabolol $(23.14,23.30 \%)$, azulene 7-ethyl-1,4-dimethyl (camazulene) $(5.42,4.82 \%)$, bisabolol oxide A $(16.17,14.91 \%), 1,6$-dioxaspironon-3-ene $(11.20,10.52 \%)$. The identity of components of essential oil was confirmed on the basis of retention time, mass and supplemented library of NIST, USA.
\end{abstract}

Key Words: Matricaria recutita L. Asteraceae, Steam and hydrodistilled essential oil, Major and minor constituents.

\section{INTRODUCTION}

Matricaria recutita L. (syn. Chamomilla recutita L., family Asteraceae), popularly known as German chamomile, is a native of Europe and adjoining Asian countries. It is an important medicinal and aromatic plant used in both traditional and modern systems of medicine. The flowers of this plant yield blue essential oil, which has wide application in medicine, cosmetics, foodstuffs and in the flavouring of alcoholic and non-alcoholic beverages. Both the flowers and the essential oil have been reported to possess antiinflammatory, spasmolytic, antiseptic, carminatic, sedative and ulcer-protecting properties $^{1,2}$. The therapeutic value of chamomile flowers has been attributed due to the presence of flavonoids and coumarins in the essential oils ${ }^{3}$.

German chamomile was introduced long back in the country and is being presently cultivated in H.P., J \& K, Assam and in some regions of northern India. The flowers of German chamomile accumulate blue essential oil from 0.2 to $1.0 \%$ yield and possesses strong characteristic odour and bitter flavour. It is more or less viscous liquid. The quality of oil is usually judged on the basis of the contents of $\alpha$-bisabolol and chamazulene that are reported to have high antiphlosgistic activity.

The main constituents of the essential oil were identified as bisabolol oxides $\mathrm{A}$ and $\mathrm{B}, \beta$-farnesene, $\alpha$-bisabolol, chamazulene and 1,6-dioxaspiro non-3-ene. All the compounds except $\beta$-farnesene were reported to possess antiinflammatory and antispasmolytic activities at different levels ${ }^{4}$. The blue colour of the essential oil is due to chamazulene (an azulene), which is an artifact formed from matricine (prochamazulene), a natural constituent of the flower during hydro or steam distillation.

Although the composition of essential oil of $M$. recutita have been studied by several groups ${ }^{5-12}$ and substantial data of its chemical composition is available, there are no complete previous essential oil reports that have been recorded for north east region of India. In the present work, we have investigated the chemical composition of the steam and hydro distilled volatile oil of Matricaria recutita flowers by gas chromatography-mass spectroscopy analysis and identified 32 (I) and 34 (II) compounds, respectively.

\section{EXPERIMENTAL}

Dried flowers of $M$. recutita were obtained from north east regions of India

Essential oil isolation: The dried flowers Chamomile were subjected to hydro and steam distillation in a stainless steel mini distillation unit for a minimum period of 10-12 h. The resulting essential oils were obtained in a yield of 0.40 and $0.50 \%$ respectively. The essential oils after drying over anhydrous sodium sulphate were stored at $4{ }^{\circ} \mathrm{C}$ until use.

Gas chromatography-mass spectrometry analysis of essential oil: The GC-MS data were obtained on a Shimadzu 
QP-2000 instrument. GC conditions were: $60-250{ }^{\circ} \mathrm{C}$ at $10^{\circ} \mathrm{C} /$ min, with an internal hold time of $5 \mathrm{~min}$; carrier gas, He at a flow rate of $2 \mathrm{~mL} / \mathrm{min}$. A fused silica capillary column HP-5 was used ( $25 \mathrm{~m} .0 .25 \mathrm{~mm}$ i.d., film thickness $0.25 \mu \mathrm{m})$. MS conditions were: EI mode, $70 \mathrm{eV}$; ion source temperature, $250^{\circ} \mathrm{C}$.

The identification of the compounds was performed by matching their recorded mass spectra of the GC-MS data system. Quantitative data were obtained from electronic integration peak areas and comparing their retention time and mass spectra library with those found in the literature and supplemented by the Wiley (Wiley 7th Mass Spectral Library) \& NIST MS Search 2.0 (National Institute of Standards and Technology) GC-MS libraries.

\section{RESULTS AND DISCUSSION}

Chemical constituents of the steam and hydrodistilled essential oil: The constituents identified by GC-MS analysis in order of elution of VB-WAX bonded capillary column are presented in Tables 1 and 2 . The oil was dominated by variety of sesquiterpenes and sesquiterpene alcohols. The major components have been identified as $\beta$-farnesene $(10.23,11.96 \%)$,

\begin{tabular}{|c|c|c|}
\hline \multicolumn{3}{|c|}{$\begin{array}{c}\text { TABLE-1 } \\
\text { CHEMICAL COMPOSITION OF STEAM DISTILLED } \\
\text { ESSENTIAL OIL OF flowers of MATRICARIA RECUTITA } \\
\text { FROM NORTH EAST REGION }\end{array}$} \\
\hline $\begin{array}{l}\text { Retention } \\
\text { time }\end{array}$ & Compounds & $\%$ age \\
\hline 9.82 & 1,5-Heptadien-4-one, 3,3,6-trimethyl & 0.24 \\
\hline 23.40 & $\beta$-Elememe & 0.14 \\
\hline 26.15 & $\beta$-Farnesene & 10.23 \\
\hline 26.58 & trans-Limonene oxide & 3.48 \\
\hline 27.03 & Germacrene-D & 0.66 \\
\hline 27.23 & $\beta$-Selinene & 0.20 \\
\hline 27.63 & Bicyclogermacrene & 0.34 \\
\hline 27.76 & 2,3-Dihydro-2-methyl phenol & 0.14 \\
\hline 28.10 & $\beta$-Bisabolene & 0.27 \\
\hline 30.22 & 1,3,6,10-Dodecatetraene 3,7,11-trimethyl & 0.36 \\
\hline 30.62 & Furan-3-(4,8-dimethyl-3,7-nonadienyl) & 0.40 \\
\hline 30.76 & (-)-Spathulenol & 0.97 \\
\hline 31.57 & 6-Methoxyfuro chromen-2-one cyclohexanone & 0.23 \\
\hline 32.07 & 1,3,4,5,6,9-Hexahydrobenzocyclohepten-2-one & 0.52 \\
\hline 32.28 & Benzofuran 2,3-dihydro-2-methyl & 0.75 \\
\hline 32.63 & Pentanal-(4-nitrophenyl)hydrazone & 0.18 \\
\hline 32.78 & 6-Aza-2-thiothymine trimethadione & 0.85 \\
\hline 32.99 & 3-Trifluromethylbenzoic acid octyl ester & 0.17 \\
\hline 33.13 & $\begin{array}{l}\text { Naphthalene 1,2,3,5,6,8 } \alpha \text {-hexahydro-4,7- } \\
\text { dimethyl-1-(1-methylethyl) }\end{array}$ & 1.09 \\
\hline 33.81 & Bisabolol oxide B & 16.91 \\
\hline 33.96 & 3-pyrrolidinone 4,4-dimethyl-5-thioxo & 1.85 \\
\hline 34.83 & $\alpha$-Bisabolol & 23.14 \\
\hline 34.97 & $\begin{array}{l}\text { Bicycloheptane 2-methyl-3-methylene-2-(4- } \\
\text { methyl-3-pentenyl) }\end{array}$ & 1.38 \\
\hline 36.39 & Azulene 7-ethyl-1,4-dimethyl & 5.42 \\
\hline 37.07 & Bisabolol oxide A & 16.17 \\
\hline 38.81 & Bicyclohexane 6-isopropylidene-1-methyl & 0.28 \\
\hline 40.31 & 2-Pentadecanone 6,10,14-trimethyl & 0.40 \\
\hline 41.67 & 1,6-Dioxaspironon-3-ene & 11.20 \\
\hline 42.02 & $\begin{array}{l}\text { 1,6-Dioxaspiro non-3-ene 2-(2,4- } \\
\text { hexadiynylidene) }\end{array}$ & 1.18 \\
\hline 42.77 & 2-Aminophenol & 0.19 \\
\hline 43.78 & Azulen-2-ol 1,4-dimethyl-7-(1-methylethyl) & 0.30 \\
\hline 59.38 & $n$-Pentacosane & 0.38 \\
\hline
\end{tabular}

\begin{tabular}{|c|c|c|}
\hline \multicolumn{3}{|c|}{$\begin{array}{c}\text { TABLE-2 } \\
\text { CHEMICAL COMPOSITION OF HYDRODISTILLED } \\
\text { ESSENTIAL OIL OF flowers of MATRICARIA } \\
\text { RECUTITA FROM NORTH EAST REGION }\end{array}$} \\
\hline $\begin{array}{l}\text { Retention } \\
\text { time }\end{array}$ & Compounds & $\begin{array}{c}\% \\
\text { age }\end{array}$ \\
\hline 9.83 & $\begin{array}{l}\text { 1,5-Heptadien-4-one, 3,3,6-trimethyl (artemisia } \\
\text { ketone) }\end{array}$ & 0.58 \\
\hline 13.07 & Bicycloheptan-2-one 1,7,7-trimethyl & 0.12 \\
\hline 23.40 & $\beta$-elememe & 0.23 \\
\hline 24.50 & $\beta$-Caryophyllene & 0.19 \\
\hline 26.16 & $\beta$-farnesene & 11.96 \\
\hline 26.58 & Trans-Limonene oxide & 3.31 \\
\hline 27.04 & Germacrene-D & 0.77 \\
\hline 27.23 & $\beta$-selinene & 0.25 \\
\hline 27.63 & Bicyclogermacrene & 0.41 \\
\hline 27.76 & $\begin{array}{l}\text { 1-Ethenyl-4-methoxy-benzofuran 2,3-dihydro-2- } \\
\text { methyl }\end{array}$ & 0.17 \\
\hline 28.10 & $\beta$-Bisabolene & 0.31 \\
\hline 28.68 & $\delta$-Cadinene & 0.17 \\
\hline 30.22 & 1,3,6,10-dodecatetraene 3,7,11-trimethyl & 0.41 \\
\hline 30.62 & Squalene & 0.44 \\
\hline 30.76 & (-)-Spathulenol & 1.06 \\
\hline 31.57 & 6-Methoxyfuro chromen-2-one cyclohexanone & 0.22 \\
\hline 32.07 & Benzene 1-(1,5-dimethyl-4-hexanyl)-4-methyl & 0.50 \\
\hline 32.28 & Cyclobutene bis (1-methylethylidene)- & 0.76 \\
\hline 32.63 & $\alpha$-Acoradiene & 0.18 \\
\hline 32.78 & Nonane 5-butyl 6-aza-2-thiothymine & 0.76 \\
\hline 33.13 & $\begin{array}{l}\text { Naphthalene 1,2,3,5,6,8 } \alpha \text {-hexahydro-4,7- } \\
\text { dimethyl-1-(1-methylethyl) }\end{array}$ & 1.01 \\
\hline 33.80 & Bisabolol oxide B & 17.43 \\
\hline 33.95 & 3-Pyrrolidinone 4,4-dimethyl-5-thioxo & 1.61 \\
\hline 34.83 & $\alpha$-Bisabolol & 23.30 \\
\hline 34.96 & 1H-pyrrole-2-ethyl-4-methyl & 1.18 \\
\hline 36.38 & Azulene 7-ethyl-1,4-dimethyl (camazulene) & 4.82 \\
\hline 37.06 & Bisabolol oxide A & 14.91 \\
\hline 38.81 & 1,5-dimethyltricyclo octane & 0.24 \\
\hline 40.31 & 2-Pentadecanone 6,10,14-trimethyl & 0.36 \\
\hline 41.65 & 1,6-Dioxaspironon-3-ene & 10.52 \\
\hline 42.01 & $\begin{array}{l}\text { 2-(2,4-hexadiynilidene)-1,6-dioxaspiro non-3- } \\
\text { ene }\end{array}$ & 1.04 \\
\hline 42.77 & $\begin{array}{l}\text { None-3-ene 3-methyl-2-(3,7, 11- } \\
\text { trimethyldodecyl) furan }\end{array}$ & 0.17 \\
\hline 43.78 & Azulen-2-ol 1,4-dimethyl-7-(1-methylethyl) & 0.28 \\
\hline 59.38 & Pentacosane & 0.31 \\
\hline
\end{tabular}

limonene oxide $(3.48,3.31 \%)$, bisabolol oxide B (16.91, $17.43 \%)$, $\alpha$-bisabolol $(23.14,23.30 \%)$, azulene 7-ethyl1,4-dimethyl (camazulene) (5.42, $4.82 \%)$, bisabolol oxide A $(16.17,14.91 \%)$ and 1,6-dioxaspironon-3-ene $(11.20$, $10.52 \%)$ in steam and hydrodistilled oil. However, the comparison of our results with literature ${ }^{3,4,6}$ shows some qualitative and quantitative differences in the composition of chamomile oil. The identification of the compounds was performed by matching their recorded mass spectra of the GC-MS data system. Quantitative data were obtained from electronic integration peak areas and comparing their retention time and mass spectra library with those found in the literature and supplemented library. Other methods of identification and took help of by comparing mass data with data of library ${ }^{13,14}$. Variation in the chemical composition of the essential oil of $M$. recutita during steam and hydrodistillation revealed that the change concentration of constituents have been observed. 


\section{ACKNOWLEDGEMENTS}

The authors are highly grateful to M/S Flowers Valley Agrotech Private Limited, Hojai, Nogaon, Assam, India for providing the dry flowers for experimental studies.

\section{REFERENCES}

1. K.V. Shashidhara, R.S. Verma and P. Ram, Flav. Frag. J., 21, 274 (2006).

2. M. Das, G.R. Mallavarapu and S. Kumar, J. Med. Arom. Plants Sci., 20, 1074 (1998).

3. C. Mann and E.J. Staba, J. Herbs Spices Med. Plants., 1, 236 (1986).

4. V. Jakovlev, O. Issac, K. Thienner and R. Kundu, Planta Med., 35, 125 (1979).

5. R.K. Lal, J.R. Sharma and H.O. Mishra, Pafai J., 1, 7 (1986).
6. J. Reichling, R. Beiderbeek and H. Beeker, Planta Med., 36, 322 (1979).

7. J. Reichling, W. Bisson, H. Beeker and G. Schilling, Z. Naturforsch., 38, 159 (1983).

8. H. Vuorela, Y. Holm, R. Hiltunen, T. Tarvela and A. Laitanen, Flav. Fragr. J., 5, 81 (1990).

9. D. Grgesina, M.L. Mandic, L. Karuza, T. Klapec and D. Bockinac, Prehrambeno-Tehnol. Biotechnol. Rev., 33, 111 (1995).

10. E. Reverchon and F. Senatore, J. Agric. Food Chem., 42, 154 (1994).

11. A. Raal, E. Arak, A. Orav and K. Ivask, ARS Pharmaceut., 44, 150 (2003).

12. A. Orav, T. Kailas and K. Vask, Proc. Eston. Acad. Sci. Chem., 50, 39 (2001)

13. W.A. Konig, D. Joulain and D.H. Hochmuth, Terpenoids and Related Constituents of Essential Oils (2004).

14. D.H. Hoch, Mass Finder 3.0 (2005). 